\title{
ALIGNMENT OF TOTAL QUALITY MANAGEMENT IN THE HIGHER EDUCATION CONTEXT
}

\section{Everard van Kemenade ${ }^{1,+}$, Alaa Eldin El-Asawi², Cuong Huu Nguyen ${ }^{3}$}

\section{Article History}

Received: November 15, 2019

Accepted: February 20, 2020

Published: March 30, 2020

\section{Keywords}

Total Quality Management, $\mathrm{TQM}$, teaching and learning, holistic quality model, higher education
${ }^{1}$ Utrecht University of Applied Sciences, the Netherlands; ${ }^{2}$ Center for Quality \& Hospital Qualification for Accreditation (ArCQQA), Egypt; ${ }^{3}$ Ton Duc Thang University, Vietnam

${ }^{+}$Corresponding author $\bullet$ Email: everardvankemenade@gmail.com

\section{INTRODUCTION}

Nguyen Huu Cuong et al. (2017) draw five lessons learned from the establishment and development of Vietnam's accreditation. Lesson 5 relating to building quality culture and developing internal quality assurance system is crucial for institution's quality enhancement. Building a quality culture, they state, always goes with developing an internal quality assurance system within an institution. Internal quality assurance using TQM and its European equivalent the European Foundation for Quality Management Excellence Model started in Western countries almost 50 years ago and generated great interest in most firms in the beginning. Grant et al. (1994), Dalrymple \& Drew (2000) and Yeung et al. (2006) emphasise that TQM means a paradigm shift. One of the most distinguishing factors of TQM companies mentioned is the centrality of the human or 'soft' factor in the way to continuous improvement.

TQM had its ups and downs (Hermel, 1997). Interest declined in the end of the eighties and revived in the beginning of the nineties of last century. At the moment TQM is still in practice, often next to new methods like lean management and Six Sigma. Although research on TQM reports mixed results, the main tendency is that TQM is said to work, that it actually improves the quality of the business. "Continuous improvement and problem prevention significantly enhance job satisfaction and organizational commitment" (Karia \& Assaari, 2006, p. 30). According to Ooi et al. (2007), where teamwork was perceived as a dominant TQM practice, improvements in job satisfaction levels were significant. TQM has been successfully implemented in different contexts, in manufacturing as well as in services (Sureshchandar et al., 2001), in Western countries as well as in emerging countries (Martin and Weill, 2000) or in Arabic countries like Qatar (Al-Khalifa and Aspinwall, 2000), Yemen (Al-Zamany et al., 2000) and Egypt (e.g. Elghamrawy and Shibayama, 2008; Salaheldin, 2003).

It is important to know what factors influence the success of TQM. One of the main critical success factors for TQM implementation reported in scientific research is that senior management should be committed (Bayaktar et al., 2008; Bin et al., 2009; Chowdury et al., 2007; Evans, 1995; Soltani et al., 2008). Hirtz et al. (2007) specify this (for administrative/ service organizations) by saying that transformational leadership appears to be critical in the successful implementation of quality management. Furthermore, there is broad consensus that employees need to be involved (Bayaktar et al., 2008; Bin et al., 2009; Chowdury et al., 2007; Gatchalian, 1997; Hoogervorst et al., 2005; Krüger,1998; Ooi et al., 2007; Sun et al., 2000; Rahman, 2004; Yen, 2003) or that there should be strong internal 
motivation (Van der Wiele et al., 2000). These factors can be summarized in the need for Commitment. There should be emotional involvement to the implementation (Van der Wiele et al, 2000) or - in a broader sense - a quality Culture (Fuchs 1993). Fuchs (1993) adds the lack of focus on strategic planning as roadblock for companies that strive to use TQM for competitive advantage. Bayaktar et al. (2008) mention the importance of a vision. We here call this factor Concept, which includes a company's mission, values and vision.

Commitment, Culture and Concept are the drivers for the Paradigm Change if the company and its TQM system fits to the Context. Sousa \& Voss (2001) strongly suggest that process quality management practices are contingent on a plant's manufacturing strategy. They argue that rigorous academic studies have raised doubts as to the universal validity of the whole set of quality management practices. Conti (2007) calls this the contingency view and states that adaptation of the model to the characteristics of the organization should be always pursued. This leads us to our theoretical construct, The Van K. Esawi Tower of TQM (see Figure 1). The authors aim to adjust the concept of TQM to higher education institutes and make it fit for use there, based on the theoretical construct provided by the The Van K. Esawi Tower of TQM.

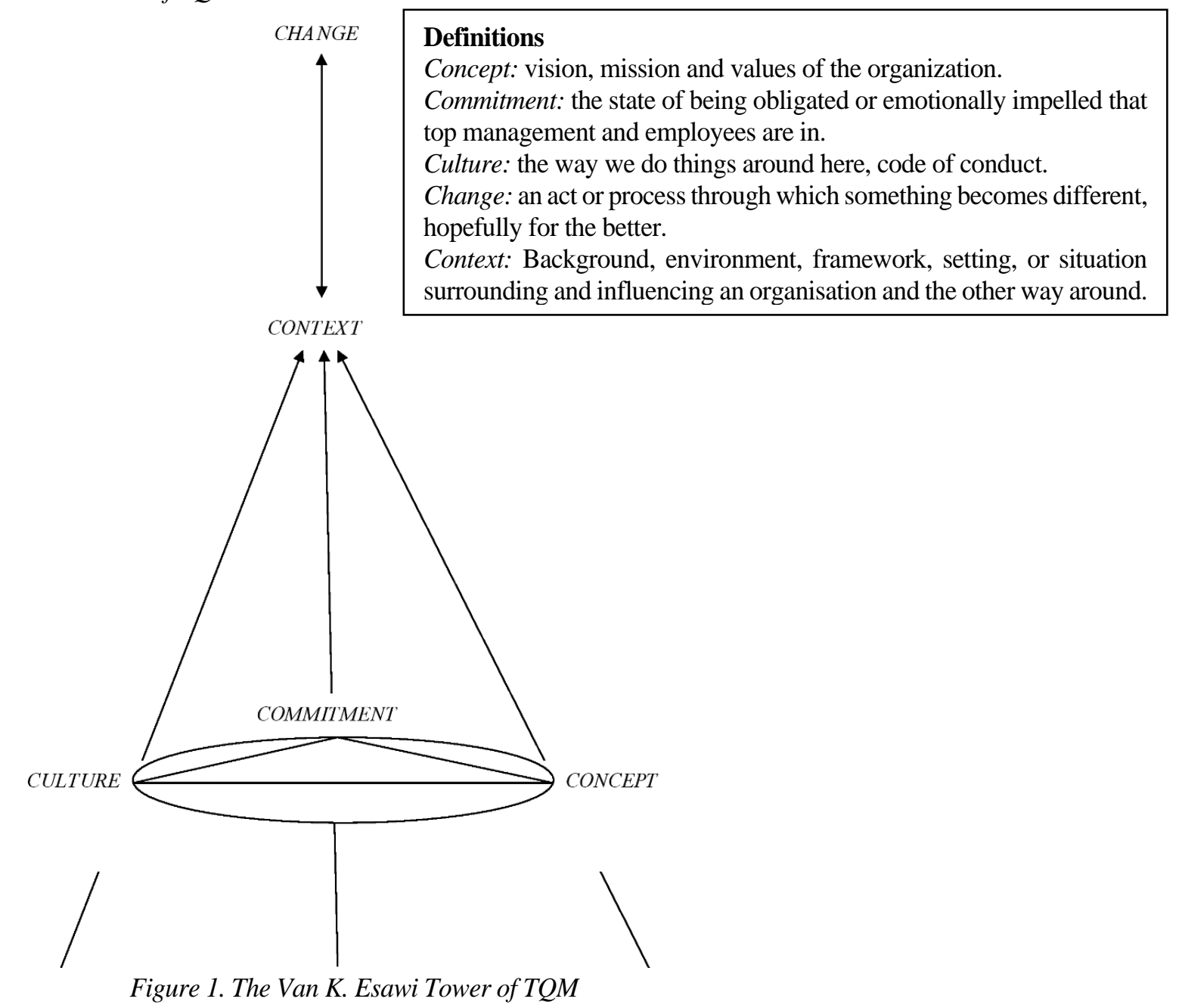

\section{LITERATURE REVIEW}

All over the world, the pressure on higher education institutions caused by expansion and increase in student numbers, cultural diversification, cuts in funding levels and accelerated changes reflected drastically in the society needs and marketplace requirements. To find answers to these challenges management cultures from the business and manufacturing industry are imported into the public sector generally and higher education in particular. This constitutes the challenges inherent in defining, developing, and demonstrating a TQM model in colleges and universities. TQM has been implemented in educational settings with mixed success (Bergquist et al., 2005). 
The resistance is strong (Koch \& Fischer, 1998; Minelli et al., 2008; Temple, 2005). That leads Harvey (1995, p. 135) to conclude: "There is no overwhelming evidence that, in the higher education context, TQM does you good". Sirvancy (2004) focuses on the difficulties, but stays positive. Weller and Hartley (1994) stress the usefulness of TQM for higher education. Pupius (2002) and Van Kemenade et al. (2004) developed models for higher education based on the European Foundation for Quality Management Excellence Model. The latter, originally Dutch, has been translated into English, German, Czech, Latvian, French, Spanish and even Vietnamese. Motwani and Kumar (1997) report improved communication, higher employee morale, increased productivity, improved process efficiency and reductions in defects and costs. Lagrosen (1999) mentions greater job satisfaction, better communication, enhanced co-operation between departments and improved leadership. Saktival et al. (2000), Wiklund et al. (2003), Hides et al. (2004), Agarwal et al. (2011) all report positive results as well.

Critical factors mentioned in the higher education context fit into the Van K. Elsawi Tower. Some research states the importance of commitment of the top management (Van Kemenade, 2010; Van Kemenade \& Hardjono, 2010; Van Kemenade et al., 2011; Sakthivel, 2000; Schaik et al., 1988). Also commitment of educational staff is mentioned (Crawford \& Shutler, 1999; Kemenade, 2009). The culture is important (e.g. control and improvement should be separated, Kemenade, 2009, 2010). Ali et al. (2010) mention visionary leadership (part of "concept") as one of the critical success factors. One of the main issues in the research to make TQM in higher education work is it should be adapted to the context (Carter \& Swanwick, 2006; Davies, 2004; Helms et al., 2001; Kwan, 1996; Osseo-Asare \& Longbottom, 2002; Pupius, 2002; Schaik et al., 1998; Taylor \& Hill, 1991; Zink \& Voss, 1999).

Design method: Adjustment to the educational context. The argument sought here is to define the TQM model that can be applicable in the higher education context. An 'ideal educational system' should incorporate the following 'learning insights':

- Learning is about transforming the student into a flexible thinker;

- Learning occurs all the time; all situations are therefore a learning opportunity;

- Learning occurs best in the context of a compelling present problem;

- Frequent feedback reinforces learning effects;

- Learning occurs best in an interpersonal context, working harmoniously with others, etc.

However, the problem lies in the very fact that at the organization level, a typical university in the many countries is not yet ready to respond to the above-mentioned requirements. Their pattern of approach seems to be characterized by the following:

- Academic programs tend not be student-centred;

- Lack of systemic thinking, consistent leadership for change and continuing approach for improvement.

As a result, curriculum and instructions are not clearly conducive for producing learning gains, as characterized by a debilitating fragmentation of learning experiences. Instructional paradigms which feature only individual work undermine the positive results on the effectiveness of collaborative learning. There is minimal feedback on performance. In addition to its focus on the continuous improvement principle, TQM also focuses on the principle of customer satisfaction. Although some academics are uncomfortable with the idea of students as customers, few would argue that we listen enough to our students, and fewer still would assert that we cannot improve our programs and services by seeking evaluations from our students.

That is why the enthusiasm of the academics to TQM has never been very high. Therefore, the only logical conclusion one can arrive at in relation to a model for quality management in higher education is that it would have to be more holistic to flexibly address service and pedagogical aspects uniquely.

The need for distinct approaches to the service and teaching areas of higher education proposed is based on their distinctiveness of emphasis. In the service areas, student is clearly the customer and is the focus of all processes. In teaching and research, students play the key role of a participant and the focus is on the attribute of their learning, as determined by:

- The global parameters of content and resources governing the curriculum design, and

- The subtle parameters of delivery and assessment governing the 'enhancement' of the learner.

$\mathrm{TQM}$ addresses the service areas, focusing on the products of delivery by measuring, monitoring and continuously improving the processes. Quality management of teaching and learning (QMTL), on the other hand, focuses on the empowerment of the course team across all the boundaries to facilitate a dialogue centred on learning. The techniques of TQM are well understood and documented in the industry practice whereas those of QMTL are 
rooted in the educational research literature, illustrated initially on the basis of a synthesis of the following four models Transformative Model, An Engagement Model of Program Quality, University of Learning Model and A Model for a Responsive University.

In spite of the structural difference in the scope of the two models, there is a substantial commonality of requirements in the implementation phase. First of all, their focus on students albeit to differing levels of subtlety. Secondly, at the operational level, collaboration is a key requirement in both models although the fields of interaction may vary to a large extent. Both models also require a visible commitment and support from the senior management to effectively continue to flourish. Thus, by and large, the pattern of interaction and governance required for both the approaches is the same. Al-Mazrooa et al. (2010, p. 106) state that "While each model cited in the previous section has its own unique perspective on educational quality in a university, it is necessary to examine them more closely to see if they can be described by a generic model for quality management".

\section{METHODS AND RESULTS}

\subsection{Methods}

In this article, a literature review has been executed, using the berry-picking technique (Bates, 1998). This technique of literature search is much closer to the real behavior of information searchers than the traditional model of information retrieval is, and, consequently, will guide our thinking better in the design of effective interfaces.

This term is used by analogy to picking huckleberries or blueberries in the forest. The berries are scattered on the bushes; they do not come in bunches. One must pick them one at a time. One could do berrypicking of information without the search need itself changing (evolving), but in this article, the attention is given to searches that combine both of these features (Bates, 1998, p. 1).

Thereafter the data has been analysed and discussed between the authors, leading to a new model for quality management in higher education.

\subsection{Findings}

The literature search led to characteristics of TQM in higher education, 6 components of the comprehensive quality model and finally to a framework for TQM in higher education.

\subsubsection{Characteristics of TQM in higher education}

Having laid out an exploration of both the above-mentioned models, we designed a comprehensive quality model that is characterized by:

- A reconciliation or sound blend of TQM and quality models (Transformative Model, An Engagement Model of Program Quality, University of Learning Model, A Model for a Responsive University), based on more integrated and interdependent system or process.

- Embracing the cultural and contextual variations through developing a conducive culture and empowering environment adaptive to new developments and changes.

- Mandatory assessment and selection process pretesting the program entrants (students) to measure their background knowledge and skills to fit with the selected programs requirements.

- A focus on the marketplace requirements to ensure the responsiveness of programs outcomes and students' knowledge and skills are responsive to these demands and requirements.

- Constant feedback and evaluation of all components for perusing an overall continuing improvement.

- Effective institutional engagement with community stresses its external relationship and interaction.

3.2.2. Components of the comprehensive quality model

The comprehensive quality model has 6 components embedded in the context, culture and commitment: educational inputs, educational objectives, connected program requirements, student experience, learning outcomes and evaluation and continuous improvement.

1. Educational Inputs

The educational inputs refer to:

- Diverse and engaged participants highlighting the pivotal role that the faculty, students and leaders play. Assessing their backgrounds, traits and needs using appropriate selection tools are mandatory.

- Leadership defining the company's concept (mission, values and vision).

- Adequate educational resources: nature of facilities and support for students, faculty and basic infrastructure.

2. Educational Objectives 
The educational objectives refer to statements that describe career and professional accomplishments that the learning is preparing graduates to achieve. (National) Academic Reference Standards and intended learning outcomes based on external context analysis. Intended learning outcomes are statements that describe what students are expected to learn and be able to apply by the time of graduation (knowledge, skills and attitude).

3. Connected Program Requirements

The connected program requirements that refer to curriculum development and within course development, e.g. leading to course manuals.

4. Student Experience

The student experience refers to:

- Interactive teaching and learning classrooms experience.

- Interpersonal context.

- Out- of-class experiences including: co-curricula, internships and support services.

- Research.

5. Learning Outcomes

The learning outcomes are subject to performance criteria that are specific measurable statements identifying the performance(s) required to meet the outcome, confirmable through evidence (e.g. in the quality of the thesis). Besides, learning outcomes refers to:

- External relationships including social engagement with communities.

- Achieving the stated outcomes of the learning process and reaching out to the community through effective relationship and participation will help, among other things in boosting the organizational ranking (employer ranking) that consider measures of research excellence and/or influence and social engagement, student choices, eventual success and others.

6. Evaluation and Continuous Improvement

Evaluation and continuous improvement is the core of TQM. In this case it refers to:

- Assessment and evaluation: collection, analysis and interpretation of evidence.

- Feedback for continuous improvement.

The design principles led to a Framework for a Quality Model in Higher Education (see Figure 2).

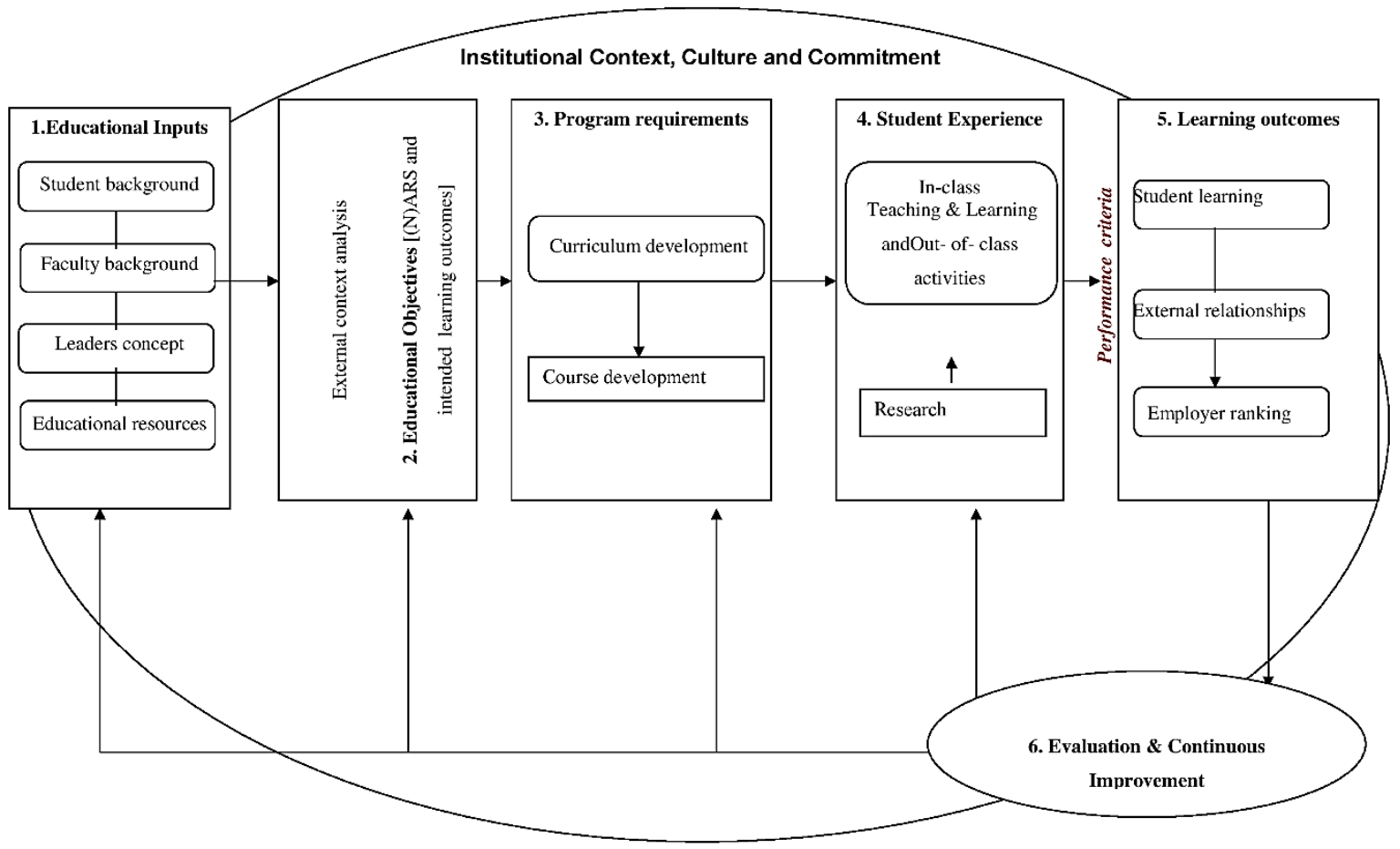

Figure 2. Framework of Quality Model in Higher Education 


\section{DISCUSSION AND CONCLUSION}

The proposed framework has been developed specifically for use in higher education. However, it might be applicable to other sectors of education as well. It was based and used mainly in two countries, Egypt and the Netherlands. It is interesting to see that it can be applied in those very different cultures. That might point to a possible universality of the framework. That would need further research, such as in an Asian country like Viet Nam to be verified. The framework developed can be used as a guideline for self-assessment. On each of the 6 components within the culture, context and commitment, a Deming cycle can be applied. It will be familiar to the academic and evoke less resistance than the manufacturing terminology like "processes", "customers" and "suppliers". Experiences with similar adjustments (Van Kemenade et al., 2004; Pupius, 2007; Schaik et al. 1998; Shaktivel \& Raju, 2006) support this proposition.

\section{REFERENCES}

Agarwal P. K., Kumar, P., Swati, G., \& Tyagi A. K. (2011). Implementing Total Quality Management in professional educational institutes in India. Advances in Management, 4(4), 18-22.

Ali, N. A., Mahat, F. \& Zairi, M. (2010). Testing the criticality of HR-TQM factors in the Malaysian higher education context. Total Quality Management, 21(11), 1177-1188.

Al-khalifa K. N., \& Aspinwall E. M. (2000). The development of Total Quality Management in Qatar. The TQM Magazine, 12(3), 194-204.

Al-Mazrooa, A., El-Deek, B., \& Ayoub, N. (2010). Applying the Total Quality Management (TQM) model and the holistic model for quality management in higher education, pros and cons. Research Journal of Medical Sciences, 4(2), 102-106.

Bates, M.J. (1989). The design of browsing and berrypicking techniques for the online search interface. Los Angeles: Graduate School of Library and Information Science, University of California. Retrieved 18 February 2020 from https://pages.gseis.ucla.edu/faculty/bates/berrypicking.html

Bayraktar, E., Tatoglu, E., \& Zaim, S. (2008). An instrument for measuring the critical factors of TQM in Turkish higher education. Total Quality Management, 19(6), 551-574.

Beck, D., \& Cowan, C. (1996). Spiral dynamics: Mastering values, leadership, and change. Malden: Blackwell Publishers.

Bergquist, B., Fredriksson, M., \& Svensson M. (2005). TQM: terrific quality marvel or tragic quality malpractice? The TQM Magazine, 17(4), 309-321.

Bin Abdullah, M. M., Uli J., \& Tari, J. J. (2009). The relationship of performance with soft factors and quality improvement. Total Quality Management, 20(7), 735-748.

Bogue, E. G. (1998). Quality assurance in higher education: The evolution of systems and design ideals. New Directions for Institutional Research, 25(3), 7-18.

Carter, G., \& Swanwick, J. (2006). Where next for quality? Is it beyond 9 box models? World Congress for TQM 11-13 April 2006. Wellington, New Zealand.

Chowdhury, M., Paul, H., \& Das, A. (2007). The impact of top management commitment on Total Quality Management practice: An exploratory study in the Thai garment industry. Global Journal of Flexible Systems Management, 8(1\&2), 17-29.

Conti, T. (2007). A history and review of the European Quality Award Model, The TQM Magazine, 19(2), 112-128.

Crawford, L. E. D., \& Shutler, P. (1999). Total Quality Management in education: Problems and issues for the classroom teacher. The International Journal of Educational Management, 13(2), 67-72.

Davies, J. (2004). The implementation of the EFQM's Excellence model in academic units of UK Universities. Salford: University of Salford.

Elghamrawy, T., \& Shibayama, T. (2008). Total Quality Management implementation in Egyptian Construction Industry. Journal of Management in Engineering, 24(3), 156-161.

Evans, R. (1995). In defence of TQM. The TQM Magazine, 7(1), 5-6.

Fuchs, E. (1993). Total Quality Management from the future: Practices and paradigms. The Quality Management Journal, 1(1), 26-34.

Gatchalian M. M. (1997). People empowerment: The key to TQM success. The TQM Magazine, 9(6), 429-433. 
Harvey, L. (1995). Quality assurance systems, TQM and new collegialism. Birmingham: The University of Central England.

Helms, M. M., Williams, A. B., \& Nixon, J. C. (2001). TQM principles and their relevance to higher education: The question of tenure and post-tenure review. The International Journal of Educational Management, 15(7), 322331.

Hermel, P. (1997). The new faces of total quality in Europe and the US. Total Quality Management, 8(4), 131-143.

Hides, M. T., Davies, J., \& Jackson, S. (2004). Implementation of EFQM excellence model self-assessment in the UK higher Education sector - lessons learned from other sectors. The TQM Magazine, 16(3), 194-201.

Hirtz, P. D., Murray, S. L., \& Riordan, C. A. (2007). The effects of leadership on quality. Engineering Management Journal, 19(1), 22-27.

Holmes, G., \& Mc. Elwee, G. (1995). Total quality management in higher education: How to approach human resource management. The TQM Magazine, 7(6), 5-10.

Hoogervorst, J. A. P., Koopman, P. L., \& Van der Flier, H. (2005). Total quality management: The need for an employee-centred, coherent approach. The TQM Magazine, 17(1), 92-106.

Iman, H. A. A. S. (2009). The role of self-assessment in architectural education quality. Cairo: Master of Science in architecture, Cairo University.

Karia, N., \& Assaari, M. H. A. H. (2006). The effects of total quality management practices on employees' workrelated attitudes. The TQM Magazine, 18(1), 30-43.

Koch, J. V., (2003). TQM? Why is its impact in higher education so small? The TQM Magazine, 15(5), $325-333$.

Koch, J., \& Fisher, J. (1998). Higher education and Total Quality Management. Total Quality Management, 9(8), 659-668.

Krüger, V. (1998). Total quality management and its humanistic orientation towards organisational analysis. TQM Magazine, 10(4), 141-145.

Kwan, P. Y. K. (1996). Application of total quality management in education: retrospect and prospect. The International Journal of Educational Management, 10(5), 25-35.

Lagrosen, S. (1999). TQM goes to school: an effective way of improving school quality. The TQM Magazine, 11(5), 328-332.

Martin, J., \& Weill, M. (2000). Emerging countries and business excellence. Total Quality Management, 11(4/5\&6), 608-615.

Minelli, E., Rebora, G., Turri, M., \& Huisman, J. (2006). The impact of research and teaching evaluation in universities: Comparing an Italian and a Dutch case. Quality in Higher Education, 12(2), 109-124.

Motwani, J., \& Kumar, A. (1997). The need of implementing total quality management in education. The International Journal of Educational Management, 11(3), 131-135.

Nguyen Huu Cuong, Ta Thi Thu Hien \& Nguyen Thi Thu Huong (2017). Achievements and Lessons Learned from Vietnam's Higher Education Quality Assurance System after a Decade of Establishment. International Journal of Higher Education, 6(2), 153-161. https://doi.org/10.5430/ijhe.v6n2p153

Ooi, K. B., Baker, N. A., Arumugam, V., Vellepan, L., \&Loke, A. K. Y. (2007). Does TQM influence employees’ job satisfaction? International Journal of Quality and Reliability Management, 24(1), 62-77.

Osseo-Asare, A. E., \& Longbottom, D. (2002). The need for education and training in the use of the EFQM model for quality management in UK higher education institutes. Quality Assurance in Education, 10(1), 26-36.

Peterson, G. D., \& Rogers, G. M. (2009). Quality assurance and accreditation of higher education programs. Paper presented at the Workshop Quality in Higher Education, 11 March 2009, Cairo.

Pupius M. (2007). Quality management in higher education institutions: An inevitable necessity? Hochschulrektorenkonferenz, Bonn, 8 October 2007.

Pupius, M. (2002). Achieving excellence in education in Europe. Egitimide Surekli Kalite Gelistirme: Uluslararasi Basari Onekleri Sempocyumu, 6 September 2002, Istanbul, Turkey.

Rahman, S. U. (2004). The future of TQM is past. Can TQM be resurrected? Total Quality Management, 15(4), 411422.

Sakthivel P. B., \& Raju, R. (2006). Conceptualizing Total Quality Management in engineering education and developing a TQM educational excellence model. Total Quality Management, 17(7), 913-934. 
Sakthivel P. B., Rajendran, G., \& Raju, R. (2000). TQM implementation and students' satisfaction of academic performance. The TQM Magazine, 17(6), 573-589.

Sakthivel, P. B. (2007). Top management commitment and overall engineering education excellence. The TQM Magazine, 19(3), 259-273.

Salaheldin, S. I. (2003). The implementation of TQM strategy in Egypt: A field-force analysis. TQM Magazine, 10(4), 266-274.

Schaik, M., van Kemenade, E. A., van Hengeveld, F., \& Inklaar Y. (1998). The EFQM based method for continuous quality improvement adapted for higher Education. Paper presented at the Annual EAIR forum, 9-12 September 1998, San Sebastian.

Sirvancy, M. B. (2004). Critical issues for TQM implementation in Higher Education. The TQM Magazine, 16(6), 382-386.

Solatni, E., Lai, P. C., Javadeen, S. R. S., \& Gholipour, T. H. (2008). A review of the theory and practice of managing TQM: An integrative framework. Total Quality Management, 19(5), 461-479.

Srikanthan, G., \& Dalrymple, J. (2002). Developing a holistic model for quality in higher education. Paper presented at the Seventh International Conference on ISO9000 and TQM, 2-4 April 2002, Royal Melbourne Institute of Technology, Australia.

Sun, H., Hui, I. P., Tam, A. Y. K., \& Frick, J. (2000). Employee involvement and quality management. The TQM Magazine, 12(5), 350-354.

Sureshchandar, G. S., Chandrasekharan R., \& Anantharaman, R. (2001). A conceptual model for Total Quality Management in service organisations, Total Quality Management, 12(3), 343-363.

Taylor, W. A., \& Hill, F. M. (1991). Total Quality Management in higher education. The International Journal of Educational Management, 5(5), 4-9.

Temple, P. (2005). The EFQM excellence model: Higher education's latest management fad? Higher Education Quarterly, 59(4), 261-274.

Van der Wiele, A., Williams, A. R. T., \& Dale, B. G. (2000). Total Quality Management: is it a Fad, a Fashion or a Fit? Quality Management Journal, 7(2), 65-79.

Van Kemenade, E. A. (2010). Past is prologue. Know the history of quality management to achieve future success. Quality Progress, 8(8), 49-53.

Van Kemenade, E. A., \& Hardjono, T. W. (2010). A critique of the use of self-evaluation in a compulsory accreditation system. Quality in Higher Education, 16(3), 257-268.

Van Kemenade, E. A., Hardjono T. W., \& De Vries, H. (2011). The willingness of professionals to contribute to their organisation's certification. International Journal of Quality and Reliability Management, 28(1), $27-42$.

Van Kemenade, E. A., Schaik, M., van Kuiper, H., Onzenoort, J., van and Biesta, E. (2004). Method for improving the quality of higher education based on the EFQM model. Groningen/Eindhoven: EFQM Working Group.

Van Kemenade, E. A., \& Hardjono, T. W. (2009). Professionals freaking out: The case of accreditation in Dutch higher education. The TQM Journal, 21(5), 473-485.

Vietnam's higher education quality assurance system after a decade of establishment. International Journal of Higher Education, 6(2), 153-161.

Weller, L. D., \& Hartley, S. H. (1994). Total Quality Management and school restructuring: Georgia's approach to education reform. Quality Assurance in Education, 2(2), 71-179.

Wiklund, H., Klefsjö, B., Wiklund, P. S., \& Edvardsson, B. (2003). Innovation and TQM in Swedish higher education institutions: Possibilities and pittfalls. The TQM Magazine, 15(2), 99-107.

Yeung, A. C. L., Cheng, T. C. E. \& Lai, K. H. (2006). An operational and institutional perspective on Total Quality Management. Production and Operations Management, 15(1), 156-170.

Zink, K. J., \& Voss, W. (1999). The new EFQM excellence model and its impact on higher education institutions. Conference proceedings from TQM for Higher Education Institutions and the Issue of Total Quality (pp. 241255), 30-31 August 1999, Verona, Italy. 